\title{
Histone Deacetylase 8
}

National Cancer Institute

\section{Source}

National Cancer Institute. Histone Deacetylase 8. NCI Thesaurus. Code C113607.

Histone deacetylase 8 (377 aa, $\sim 24 \mathrm{kDa}$ ) is encoded by the human HDAC8 gene. This protein is involved in the deacetylation of core histones. 